\title{
双極式電気メスの開発
}

\section{1. 単極式電気メスおよびその問題点}

通常の電気メスでは，図1にその構成を示す ようにメス刃状の作用電極と, 対極板, つまり 手術部位とは異なる適当な部位に広い面積で生 体に接触させた不関電極との間に高周波電流を 通電することにより，手術メスとしての効果を 得ている.これから紹介寸る双極式電気メスに 比べ，メス刃先が単極であることから，ここで は通常の電気メスを単極式電気メスと呼ばせて いただく.

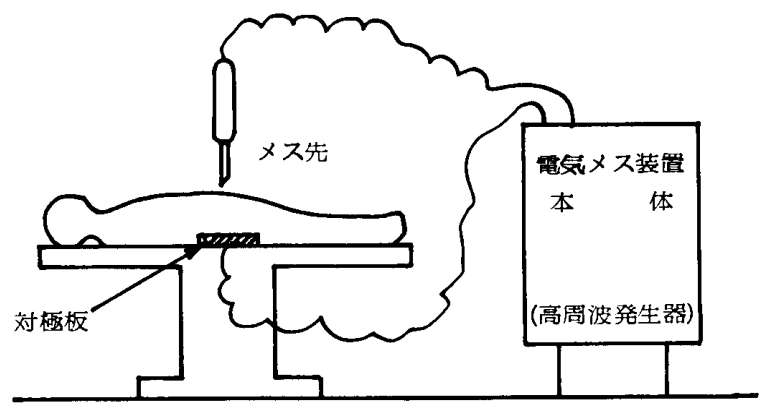

図 1 電気メスの基本構成

すでに周知のように，単極式電気メスは，も ともとの刃物のメスを除けば，比較的安価で有 用性が高く, 現在のところ最も広く普及してい る, 従来八単極式電気入又装置の本体は, 工学 的儿は結局, 大出力の高周波発生器にすぎない， しかし，すでに述べられた歴史的経過から知ら れるように, 他の $\mathrm{ME}$ 機器と切り離され, 主に 経験に基づいた独自の発展をとげたため, 現在 の機器においても発展当初の技術が枳強く残存 しているなどの理由から特徴のある高周波電力 発生装置ということができよう。

詳しくは，別の機会に述べられることと思う
東京大学医学部医用電子研究施設

池田研二

ので，ここでは電気メス装置についてはごく概 略にふれるにとどめる，まず，伝統的な装置で は, 切開用と凝固用の 2 系統の高周波発生器を 内蔵しており, 切開用のほうは, 基本的には真 空管 2 本でプッシュプル形に構成された正弦波 発振器であり，凝固用のほうは，技術的にはき わめて古い，スパークギャップを用いた減衰振 動型の高周波発生器である. 後者の発生する高 周波電流波形は複雑で, そのスペクトルの幅は 広い，実際の手術では，これら 2 系統の高周波 電流を 0 を含む適当な強度で混合して用いるこ とはご存知の通りである. 使用される周波数は, いずれも数 $\mathrm{MHz}$ 程度であり, 放電時に電気、 メ ス刚先と対極板の間に数百ないし $1000 \mathrm{~V}$ 程度 の電圧が印加され, 生体を通して数百 $\mathrm{mA} の$ 高 周波電流が流れる.

最近のトランジスタなどを用いて半導体化さ れた装置では，発振要素であるトランジスタな どの半導体素子の制約のため, 周波数が約 1 桁 低く，数百 $\mathrm{KH} \mathrm{z}$ である. 凝固用出力は, 発生 する高周波波形を正弦波から，より複雑な波形 にかえることにより得られる. 切開用から凝固 用に，波形を連続的に変化させることもでき， 混合の効果が得られる.

現在, 電気入ス以外にもレーザ光, 超音波, プラズマジェット，熱などを利用した種々の手 術用メスが提案され，一部が実用化されている ことは，すでに述べられた通りであって，それ ぞれの利点や将来性が論じられているが，電気 メスでは，とくに切開と凝固という半ば相反す る操作が簡単に切替えられる点や, 消耗部品で あるメス先の構造がきわめて簡単で交換も容易 
なこと, 出力の調整がきわめて簡単なことなど, 種々の利点を有している.

しかし同時に，刃先に然えかすが付着しやす く，しばしば刃先を掃除する必要のあることや， 燃えかすが切開面に付着，残存したときには， 傷口の治癒に時間がかかること, またとくに脂 肪の多い組織の切開に淌かないなどの問題点 もある。

さらに大きな問題点として十分に検討すべき 事項に，電気ショックおよび熱傷があり，それ らから患者を保護するといった安全性の問題が 解決されなければならない，単極式電気入スで は生体を通して高周波電流が流れるので, 電気 ショックの危険性が常に存在する。また熱傷け， 対極板が生体に十分よく接していないとき，あ るいは接地された他の金属体が不用意に生体に 接している場合などに，それらの付近で生ずる ことがある。

これらの大きな問題点を解決するひとつの方 法として，私たちの研究室では，とくにこの安 全性の面から電気入ス装置全体について再検討 を行っているが，その一環として新しい型の電 気メスである双極式電気メスを提案してその改 良，実用化の検討を行っているので，以下にメ ス刃先の改良の経過を中心にご紹介したい。

\section{2. 双極式電気メスの提案}

図 2 に単極式と双極式の電気メスによる電流 分布の模式図を示す。単極式においては，対極

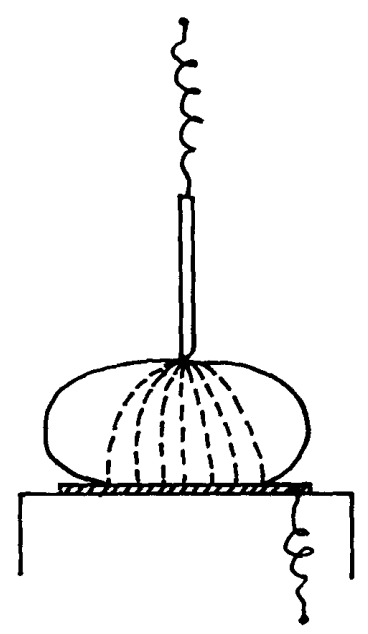

(A) 単滕式電却メス

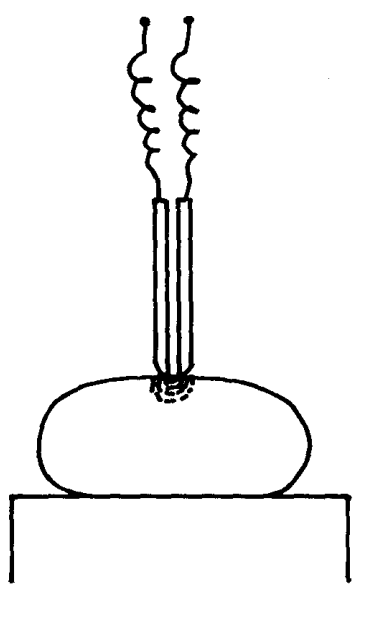

（B）双概式電司、又
図 2 電気メスによる電流分布の模式図
板が患者の腰部など手術部位の裏側で，広い面 積のとれる部分に装着され，そのために生体内 部を高周波電流が流れ，かつ対極板の接触面積 が何らかの理由で減少したときに，対極板側で も局部的に電流密度が増して熱傷のおそれが出 てくる.

そこで対極板をメス刃の近くにもってゆき， かつメス刃と同程度に小さくするとどうであろ うか。この状態が双極式の模式図である。もし メスに加えられる高周波電源回路が，フローテ イング回路あるいはアイソレータによって，完 全に接地から浮いていれば，双極メスにおいて は生体を流れる高周波電流の分布がごく一部に 極限され，身体内部を通過することがない：ま た，このように高周波電流が，メスホルダーコ 一ド, メス先, 生体, 対極板, 対極板コードと いった大きなループを作って流れることがない ので，理想的なフローティング回路あるいはア イソレータが得られる限りにおいて, 漏れ電流 の防止策が簡単となり, 安全の確保がより容易 となる。

図 3 に実際に試作した双極メス刃先の概形を 改良した順に示す. 図 3 (A)が，最初に提案され た双極メスであり，金属板でできた 2 枚の刃先 を，あるギャップをおいて平行に対向させ，間 をエアギャップのままとしておくか，あるいは 雲母など適当な絶縁材料で埋めるかしたもので ある。

この形式の双極メスは凝固用としては有効で あったが，電極間の対向面積が大きすぎて，こ のままでは放電が分散してしまうため，切開力 が弱く, 切開痕も筋となり, 不必要に広くなっ てしまうため，邓先の形状をさらに改良する必 要があった。また，2枚のメス冈の間をエアギ ヤップとしておくと，炭化した生体組織がこの 間にたまり，刃の間で持続放電が起こってしま うことがあった，そこで，高熱に耐える，ギヤ ップ充填材料として雲母板をはさんでみたが， やはり炭化物が付着し易いため同様な支障があ った．従って，きわめて頻繁に刚先を掃除また は交撸する必要があって実用的でなかった。

なお，このような双極構造のメスに，一方の 電極を対極板とする現用の装置から高周波電流 
$(18)$

を供給すると，対極板側に接続されたメス刃先 が生体からはなれた場合でも，他方のメス刃と 生体の間で放電が起こり，生体と接地線や筐体 などとの間の浮遊容量を介し，明らかに生体内 を通過する高周波電流が不用意に流れているこ とがわかり，給電部のアイソレーションについ て十分に検討する必要のあることが知られた．

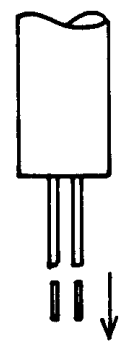

(A)

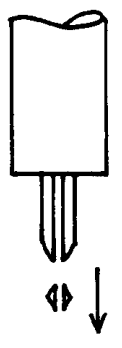

(B)

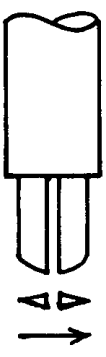

(C)

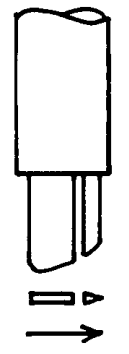

(D)

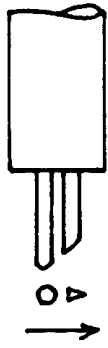

(E)

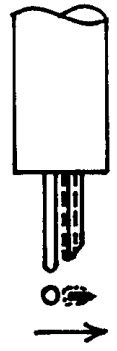

(F)
†团は切閶方向を示す。

図 3 改良過程での双極メス刃先の桠造

\section{3. 双極式電気メスの改良}

前節で述べたように，改良の方向は，(1)メス 刃先の構造, 形状の改良之 (2)高周波出力給電回 路の改良のふたつとなる。このうち(2)について は，まだ十分な検討を行っていないが(1)につい て主として切開作用の向上の観点から実験的検 討を試みてきている．他の観点には，刃先での 持続放電の防止や刃先への炭化物付着の防止な どがある。

メス刃先の評洒には特に試作したメス試験装 置を用い，放電の状況を高速度カメラで撮影し， 駒毎の火花発生位置, その連続性などを調べ, 切開に有効な位置での放電と, 切開に無効な位 置での放電の割合などを求めて行った。 高周波 発生源には現用の真空管式およびトランジスタ 式の電気メ又装置を用いた。 火花撮影にはトラ ンジスタ式っほうが便利であった。メ又試験装 置识，図 4 亿示すように任意の速度に設定でき る定速回転テーブルと，メスホルダーのグリッ プを備えたマニピュレータとから成っていて, 肉片試料を回転テーブル上に載せて，火花発生 状態や，切開痕を観測するものである。

図 3 (B)および図 5 は，(A)のプロトタイプの先 端を尖鋭化したもので，(A)に比し放電が安定化 され，切開力哇向上したが，切開痕は 2 筋であ

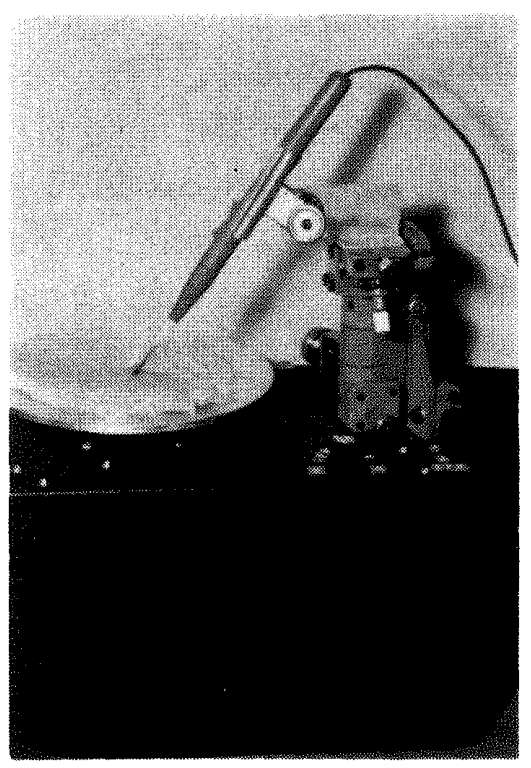

図 4 電気メス先試験装置

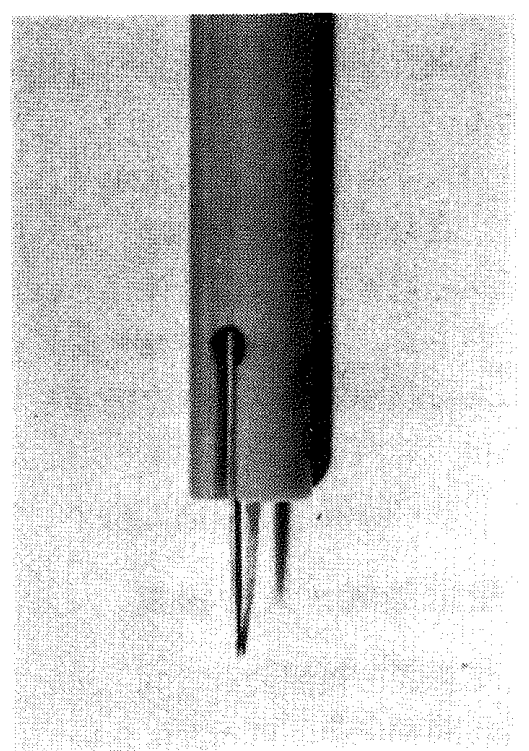

5 図試作双極メス（図 3 Bのもの）

り，かつ持続放電が生じ易いなどの久陮は依然 として残った。

そこで思い切って平板電極 2 枚を一直線上に 一列に配置してみたのが図 3 (C)である。こうす ることにより切開痕は大幅に改善されるが，こ のままでは，電極面積が大きすぎて，プロト夕 イプ(A) と同様に放電が不安定となり，切開力が 不足であった。また，このような対称構造のも のでは，前傾約 $30^{\circ}$ といったメスを使う際の自 然な角度で肉片を切万うとすると，進行方向に 先行するエッジからの放電がむしろ少なく，か つ後側になる刚が生体から離れがちで，メスを 真直に立てるか，むしろ逆に後傾がちで使う必 


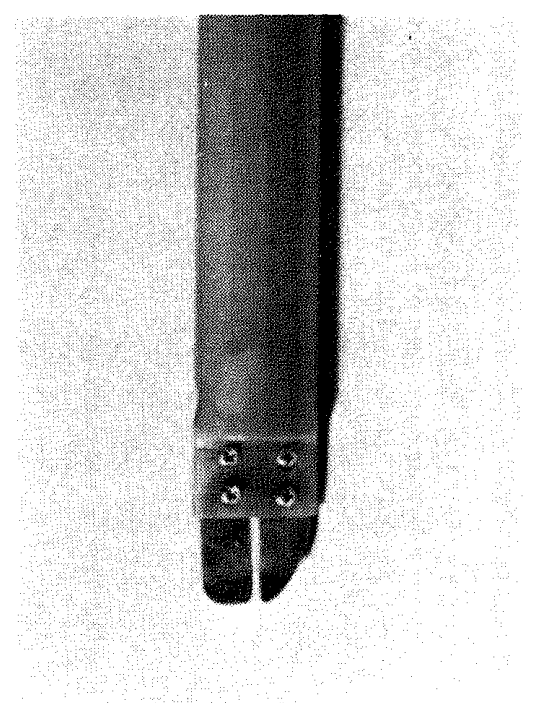

図 6 試作双極メス（図 3 D のもの）

要があった。このような点から，一列形の双極 メスにおいては，非対称構造とせざるを得ない ことが知られた。

図 3 (D) および図6は以上のことを考慮して平 板電極の大きさを変え，方向性をもたせたもの である，放電は尖鋭化されたほうの阮先で，か なり安定に発生し，その方向に切り進むとき, 切開作用は円滑に進行寸る. しかし，後方電極 が組織面から離れると, 放電が後方電極に移り, 急に切開しにくくなる. 後方電極は, 前方電極 のエッジで切開された跡をたどるので, 組織面 から離れるような状況は容易に発生寸る。これ を防ぐためには, 後方電極のほうがやや太く, かつ多少突き出ているのがよい。こうすると, 切り始めに执いて，多少使いゔらくなるが，こ れは止むを得ないであろう。

このような意図で作られた刃先が図 3 (E)に示 すもので，後方電極を円柱状とし，さらに若干 長くして劣る。これにより放電が一層前方電極 に集中し，切開作用が順調となる. 円柱状電極 の直径は $2 \mathrm{~mm}$ 程度が最適であった. 図 $3(\mathrm{~F})$ お よび図 7 は切開側電極をさらに溶融ガラスでお おい，ナイフエッジのみ磨き出したもので，放 電の方向性をな扔一層向上させることができた． 図 8 にこの双極式電気メスの切開痕を単極式の ものと比較して示した．条件にもよるが，単極 式と ‘切れ味’の上ではさほど変らないまでにな ったが，切開痕の幅がやや広いことが知られる

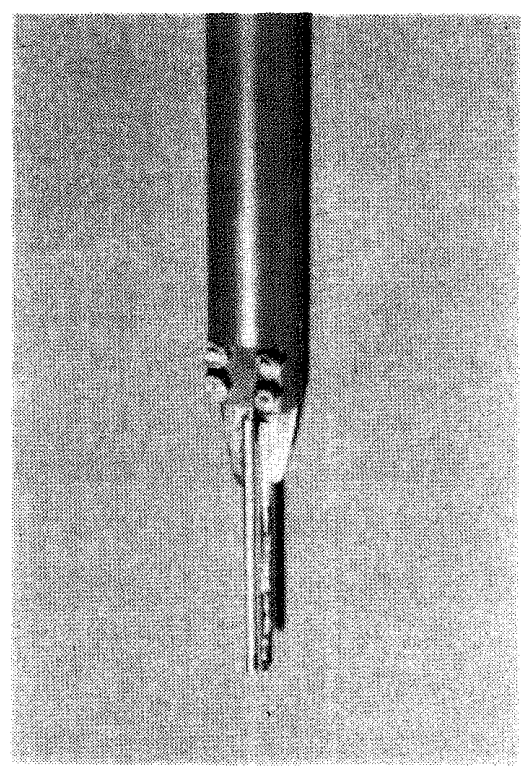

図 7 試作双極メス（図 $3 \mathrm{~F}$ のもの）

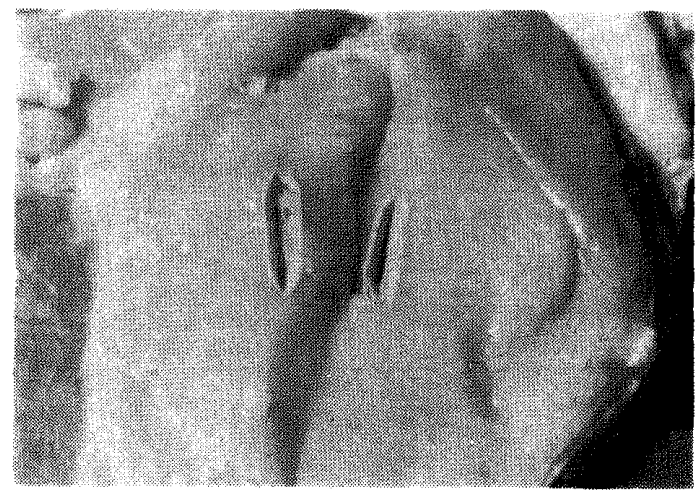

図8 単極メス（右）および双極メス（左） の切開痕

であろう。

\section{4. 結 論}

(1)双極入ス猜については，改良を加え，か なり満足のできるものに近つけることができた が，現状では，まだ切開力においても単極メス に劣るといわざるを得ない。しかし，使用部位， 目的によっては十分に利用可能である. 双極が 同時に接触する必要があるため, 使用できる部 位或いは手技上の制約がある，また持続放電に ついては，一列形でほぼ解決できている。しか し炭化物の付着については, なお末解決といわ ざるを得ない。

(2)高周波出力回路のアイソレーションについ ては，本格的な検討がまだ行われていない。た だ，ひとつの実験事実として, 直径 $3 \mathrm{~cm} の$ 単 層コイル（フェライトコア入り）によるアイソ 
(20)

レータ・トランスを試作し，現用装置と双極メ ス刃先の間に插入し，対地容量を減ずることが できたが，なお完全ではなかった：これを完全 化するためには，メスの柄の中にアイソレータ

・トランスを組み込む必要があろう。

以上の結果および前章までの議論をまとめて, 以下に述べる諸点がさらに結論されるものと思 われる。

(3)電気メスにおいてとくに重要とされる安全 性に関し, 双極式電気メスは, 対極板付近など での熱傷および電気ショックのいずれの面から も有利であり, 安全な電気メスとして実用化の 見込みがあること．

(4)双極入スにおける刃先の放電現象について は，なおよくわからない現象が残っており，さ らに有効な単方向化の方法を含めて, 今後の研 究が必要である。
(5)レーザ・メスなど有能で理想に近いメスが いくつか開発されつつあり, 当然将来はそれら の新しいメスが利用される機会も多くなること が予想されるが, 熟練を要さず, 操作が簡単で 安価な, 電気メスの有利な面が生かされて, 小 規模な手術室に常備されるものとして, 双極メ スを含めた電気入スの使用される場面も将来と も多く残されているものと考えられる.

なお，本開発研究は東京大学医学部医用電子 研究施設, 斎藤正男教授の研究室において, 又 吉正治, 福本一郎, 望月篤子の諸君のご協力に より進行中のものであることを一言つけ加えて おきたい。

註) 本論文は昭和52年: 9 月10日, 東京で開催された 第 1 回手術用機器研究会における講演要旨であ る.（編集部） 